\title{
NOTES BY CHAIRMAN
}

ASTIN has entered its second decade. The progress and growth during our first ten years have exceeded the aspirations of its group of founders. A recent report of our Secretary recorded current membership as follows: 623 ordinary, II2 corporate, and 2 special members.

The problems of "growing up" have been resolved so that we can devote our time during the next ten years to improving and increasing the effectiveness of actuarial science. We shall have to meet the challenge- "Is ASTIN doing well?" made at recent meetings.

The environment in which actuaries will function will intensify the need for more qualified, more vigorous and more articulate actuarial discussion with managements and regulators. Most serious will be the effects of international and national political tensions. The problems of inflation and their impact on non-life insurance will disturb the pure mathematical model approach to solutions.

The "new economics" and social programs of nations and governments will occupy the studied attention of present and future ASTIN members. The automobile will continue to generate traffic and accident problems as it increases its importance and role in transportation for both personal and business purposes. The hazards of health of our people and destructive acts of God on property will tax the skills and ingenuity of actuaries.

In smooth British fashion, ASTIN has had a "changing of the guard" in its secretarial offices in London. Mr. Robert Beard was one of the pioneers in formulation of a non-life section of the International Congress of Actuaries. He served with distinction on the ASTIN Committee as a member and as Secretary since organization. For two of those years he was also the chairman. His contributions to discussions and literature have been outstanding. We look forward to his continuing advice and counsel even after he has relinquished his position as Secretary. We welcome as his successor Mr. P. J. H. Green, who will "carry on" in the efficient tradition of ASTIN's secretarial office in London.

Norton E. MASTERSON 